\title{
Penerapan Strategi Pembelajaran Think Talk Write (TTW) dalam Meningkatan Keterampilan Menulis Teks Eksposisi Analitis pada Peserta Didik
}

\author{
Elvilida Sari Siregar \\ *Jurusan Pendidikan Bahasa Inggris Fakultas Bahasa dan Seni, Universitas Pendidikan Ganesha, Singaraja Indonesia
}

\author{
A R T I C L E I N F O \\ Article history: \\ Received 19 May 2018 \\ Received in revised form \\ 25 June 2018 \\ Accepted 10 July 2018 \\ Available online 25 August \\ 2018 \\ Kata Kunci: \\ strategi TTW, keterampilan \\ menulis, teks eksposisi \\ analitis. \\ Keywords: \\ TTW strategy, writing \\ competency, analytical \\ exposition text.
}

\begin{abstract}
A B S T R A K
Penelitian ini bertujuan mengetahui dan mendeskripsikan (1) penerapan strategi pembelajaran TTW dalam meningkatkan keterampilan menulis teks eksposisi analitis peserta didikkelas XI P2SMK Negeri 2 Singaraja tahun pelajaran 2017/2018, (2) langkahlangkah pembelajaran yang paling tepat dalam menerapkan strategi TTW dalam menulis teks analitis peserta didikkelas XI P2 SMK Negeri 2 Singaraja tahun pelajaran 2017/2018, dan (3) respons peserta didikkelas peserta didikkelas XI P2 SMK Negeri 2 Singaraja ketika mengikuti pembelajaran menulis teks teks eksposisi analitis dengan menggunakan strategi TTW. Penelitian ini terdiri atas dua siklus. Subjek penelitian ini adalah peserta didikkelas XI P2 SMK Negeri 2 Singaraja, sebanyak 40 orang. Data mengenai kemampuan menulis teks eksposisi analitis dengan menggunakan strategi TTW dikumpulkan dengan teknik tes yang diberikan pada akhir pembelajaran, langkah-langkah pembelajaran menulis teks eksposisi analitis dengan menggunakan
\end{abstract} strategi TTW dikumpulkan dengan teknik observasi, dan respons peserta didik ketika mengikuti pembelajaran menulis teks eksposisi analitis dengan menggunakan strategi TTW dikumpulkan dengan teknik observasi dan angket. Hasil penelitian menunjukkan bahwa penggunaan strategi TTW dapat meningkatkan kemampuan menulis teks eksposisi analitis siswa. Peningkatan skor rata-rata keterampilan menulis eksposisi analitis adalah sebesar 35\%, yaitu dari rata-rata $32.5 \%$ menjadi $67.5 \%$. Pembelajaran dikatakan berhasil karena peserta didikyang mendapatkan skor di atas KKM mencapai $80 \%$. Peserta didikmemberikan respons yang positif dalam mengikuti pembelajaran menulis teks eksposisi analitis dengan menggunakan strategi TTW, yakni dengan skor $92 \%$.

\section{A B S T R A C T}

This study aims at finding out and describing (1) the implementation of TTW learning strategy in improving students' writing competency in analytic exposition text in class XI P2 SMK Negeri 2 Singaraja in academic year 2017/2018, (2) the appropriate learning steps for TTM strategy implementation in writing analytic exposition text of students in class XI P2 SMK Negeri 2 Singaraja in academic year of 2017/2018, (3) students' response in class XI P2 SMK Negeri2 Singaraja while learning analytic exposition text through the use of TTW strategy. It is a two-cycles study with the total students of 40 people in class XI P2 SMK Negeri 2 Singaraja. The data of students' writing competency in analytic exposition text through the use of TTW strategy were collected through test at the end of the learning. Data of the learning procedures were collected through observation technique and data of students' response towards its implementation were collected through observation and questionnaires. The result of the study showed that the implementation of TTW strategy could improve students' writing competency in analytic exposition text. The improvement of students' writing competency was about $35 \%$, from $32.5 \%$ to $67.5 \%$. The learning session was considered to be successful for around $80 \%$ of the students could gain the scores above the standard score. The students (92\% of them) gave positive response while implementing TTW strategy in writing analytic exposition text 


\section{Pendahuluan}

Pembelajaran menulis di sekolah tercantum dalam kompetensi dasar. Berdasarkan kurikulum 2013, keterampilan menulis pada mata pelajaran Bahasa Inggris kelas XI untuk SMA/MK diantaranya adalah teks undangan resmi, teks eksposisi analitis, dan teks surat pribadi, dengan kompetensi dasar membedakan beberapa teks dan menyusun teks. Oleh karena itu, keterampilan menulis merupakan salah satu keterampilan yang harus dikuasai oleh peserta didik.

Berdasarkan pengalaman mengajar peneliti selama 2 bulan mengajar mata pelajaran Bahasa Inggris di kelas XI di SMK Negeri 2 Singaraja tahun pelajaran 2017/2018, pada topik pembelajaran menanyakan dan mengungkapkan opini, peneliti menemukan lima masalah umum yang dihadapi peserta didik dalam kegiatan menulis yang menjadi data awal peneliti melakukan penelitian, yaitu: (1) peserta didik sulit mendapatkan ide saat penugasan individu, (2) peserta didik sulit mengembangkan ide serta mengekspresikannya kedalam tulisan Bahasa Inggris, (3) kosa kata yang dimiliki peserta didik masih rendah, (4) kesalahan tata bahasa, (5) serta masih ditemukan kesalahan pada penggunaan tanda baca dan penulisan ejaan dalam Bahasa Inggris.

Data awal tersebut didukung dari hasil pre-test yang dilakukan peneliti. Berdasarkan hasil pre-test menulis teks eksposisi analitis didapat kan data yang menunjukkan bahwa hanya 15 orang peserta didik atau $32.5 \%$ di kelas XI-P2 yang mencapai KKM 70 sementara 35 orang peserta didik atau $67.5 \%$ tidak mencapai KKM tersebut. Dari 40 peserta didik yang mengikuti pre-test menulis teks eksposisi analitis, 18 orang masih tidak bisa membedakan antara teks eksposisi analitis dengan teks eksposisi hortatory. Dari hasil pre-test menulis teks ekposisi analitis tersebut, peneliti melakukan wawancara kepada peserta didik kelas tersebut untuk mencari tahu masalah sebenar yang mereka hadapi dalam menulis. Dari hasil wawancara, peneliti mendapatkan data bahwa 75\% peserta didik yang tidak tuntas menulis memiliki kesulitan dalam mendapatkan ide dan mengekspresikan ide kedalam tulisan yang runtut dan berkesinambungan, ditambah lagi kelemahan kosa kata dan tata bahasa. Hal ini juga ada hubungannya dengan tingkat kegemaran peserta didik membaca, peserta didik kesulitan memunculkan dan menuangkan ide, dan gagasan dalam menyusun teks eksposisi analitis.Kadang peserta didik merasa bosan jika diminta untuk menulis dan membutuhkan waktu yang lama dalam pengerjaannya, hal itu sangat mempengaruhi manajemen waktu dalam proses pembelajaran Bahasa Inggris yang hanya mendapatkan waktu 2 jam per minggu, dimana satu jam pertemuan terdiri dari 2 x 45 menit.

Hasil wawancara di atas sejalan dengan yang disampaikan oleh guru bidang studi Bahasa Inggrisyang mengajar di kelas XI P2 SMK Negeri 1 Singaraja. Guru bidang studi mengakui bahwa keterampilan menulis teks eksposisi analitis peserta didik tergolong rendah karena peserta didik kesulitan memunculkan dan menuangkan ide, dan gagasan dalam menyusun teks eksposisi analitis. Guru bidang studi menyatakan bahwa teks eksposisi analitis adalah salah satu teks yang sangat sulit untuk diajarkan dalam pelajaran Bahasa Inggris.

Dari permasalahan tersebut, peneliti melakukan refleksi terhadap proses pembelajaran menulis yang telah dilakukan selama ini. Dari hasil refleksi, peneliti menemukan bahwa teknik mengajar yang hanya menggunakan teknik diskusi kelompok tidak serta merta membuatpeserta didik mampu menulis dengan baik, karena tetap saja masih ada peserta didik yang dominan dalam grup dan juga ada peserta didik yang tetap pasif dan kurang berinteraksi dengan teman sekelompoknya.

Untuk mengatasi permasalahan tersebut, peneliti menawarkan strategi pembelajaran Think Talk Write (TTW) untuk meningkatkan kemampuan menulis teks eksposisi analitispeserta didik kelas XI P2SMK Negeri 2 Singaraja.Strategi pembelajaran Think Talk Write (TTW) dapat memberikan peluang kepada peserta didik untuk berinterkasi lebih banyak dengan sesama peserta didik dalam pembelajaran.Strategi tersebut juga menekankan pada kemamuan komunikasi dan kreativitas berfikir peserta didik pada tahap-tahap pelaksanaannya. Dalam tahap think yaitu berfikir, tahap talk yaitu berbicara dalam hal ini juga dimaksud berdiskusi, dan tahap write yaitu mencatat atau mengembangkan kreativitas dari hasil diskusi kedalam bentuk tulisan.

Menurut Huda (2014:218) "Think Talk Write (TTW) adalah strategi yang memfasilitasi latihan keterampilan menulis opini tersebut dengan lancar. Strategi pembelajaran Think Talk Write (TTW) ini dapat memacu peserta didik untuk berfikir, berbicara, dan menulis hasil pemikiran atau pendapatnya berdasarkan suatu topic tertentu". Berdasarkan penerapan strategi pembelajaran TTW tersebut, maka diharapkan penggunaan teknik tersebut dapat membantu peserta didik untuk menemukan ide, sehingga hasil belajar menulis peserta didikakan menjadi maksimal. Berdasarkan latar belakang yang telah dijabarkan oleh peneliti, rumusan masalah penelitian ini adalah:

"Dapatkah strategi pembelajaran Think Talk Write (TTW) meningkatkan kemampuan menulis teks eksposisi analitis peserta didik kelas XI P2 SMK Negeri 2 Singaraja Tahun Pelajaran 2017/2018?" Sesuai dengan rumusan masalah di atas, tujuan penelitian ini adalah sebagai berikut: (1) Mendeskripsikan 
langkah-langkah penerapan strategi pembelajaran Think Talk Write (TTW) untuk meningkatkan hasil belajar peserta didik dalam menulis teks eksposisi analitis di kelas XI P2 SMK Negeri 2 Singaraja, (2) Mendeskripsikan hasil belajar peserta didik kelas XI P2 SMK Negeri 2 Singaraja dalam menulis teks eksposisi analitis dengan penerapan strategi pembelajaran Think Talk Write (TTW). (3) Mendeskripsikan respons peserta didik di kelas XI P2 SMK Negeri 2 Singaraja terhadap penerapan strategi pembelajaran Think Talk Write (TTW) dalam menulis teks eksposisi analitis. Hasil penelitian ini diharapkan memiliki manfaat . penerapan strategi pembelajaran Think Talk Write (TTW).

\section{Metode}

Penelitian Tindakan Kelas (PTK) merupakan jenis penelitian yang mampu menawarkan suatu cara dan prosedur baru untuk memperbaiki dan meningkatkan kualitas proses belajar-mengajar di kelas. Dalam hal ini, cara yang ditawarkan peneliti untuk meningkatkan proses belajar-mengajar di kelas adalah penerapan strategi pembelajaran Think Talk Write (TTW) dalam menulis teks eksposisi analitis. Penelitian ini tidak hanya dilakukan dalam satu tahap, melainkan dilakukan secara bertahap atau multisiklus. Kegiatan setiap siklus meliputi: refleksi awal, perencanaan tindakan, pelaksanaan tindakan, observasi atau evaluasi, dan refleksi Dalam melakukan penelitian ini dilakukan kerjasama antara peneliti dengan pendidik bidang studi Bahasa Inggris kelas XI P2 di SMK Negeri 2 Singaraja sehingga penelitian dapat berjalan dengan lancar dan memperoleh hasil yang maksimal.

Subjek penelitian dalam penelitian ini adalah pendidik mata pelajaran bahasa Inggris di kelas XI P2 dan peserta didik kelas XI P2 SMK Negeri 2 Singaraja. Secara terperinci Objek Penelitian adalah proses pembelajaran, peningkatan kemampuan menulis teks teks eksposisi analitis dengan menggunakan teknik Think Talk Write. Secara terperinci objek yang akan diteliti dalam penelitian ini adalah langkah-langkah pembelajaran menulis eksposisi analitis dengan menggunakan teknik Think Talk Write, peningkatan kemampuan peserta didik dalam menulis eksposisi analitis dan respon peserta didik terhadap pembelajaran menulis teks eksposisi analitis menggunakan teknik Think Talk Write.

Secara umum penelitian ini menggunakan empat metode pengumpulan data, yaitu (1) metode observasi, Observasi dalam penelitian ini akan peneliti lakukan terhadap kegiatan pendidik dan peserta didik selama pembelajaran berlangsung. (2) Tes diberikan untuk mengetahui kemampuan peserta didik dalam memahami konsep dasar dan kemampuan menulis teks eksposisi analitis melalui penerapan strategi Think Talk Write di kelas XI P2 SMK Negeri 2 Singaraja. (3) Angket digunakan dalam pengumpulan data tentang respons peserta didik terhadap penggunaan strategi Think Talk Write dalam menulis teks eksposisi analitis. (4) Tujuan wawancara yang dilakukan dalam penelitian ini adalah untuk mengetahui tanggapan peserta didik mengenai pembelajaran menggunakan strategi yang diterapkan.

\section{Hasil dan Pembahasan}

Penelitian ini dilaksanakan

dalam dua siklus. Pelaksanaan siklus I menemui beberapa kendala kesulita, kendala yang dihadapi peserta didik, yaitu peserta didik masih sulit dalam memilih dan menentukan topik yang akan dijadikan sebagai bahan menulis teks eksposisi analitis. Selain itu, peserta didik masih sulit untuk memberikan argumen -argumen pendukung sesuai dengan infornasi yang ada dalam teks, kurangnya kosa kata peserta didik membuat kegiatan pembelajaran kurang kondusif. Dalam siklus I ini, berdasarkan segi proses permasalahan sebagian besar terjadi tidak hanya disebabkan keterbatasan peserta didikdalam menentukkan dan mengembangkan ide, namun juga disebabkan peserta didik kurang terbiasa menulis teks eksposisi analitis. Guru juga belum pernah menerapkan media atau metode pembelajaran untuk membantu peserta didik dalam kegiatan belajar mengajar. Hasil belajar peserta didik pada materi keterampilan menulis teks eksposisi analitis di siklus I masih di bawah KBM. Dari 40 orang peserta didik yang mengikuti praktik, sebanyak $0 \%$ peserta didik yang memperoleh nilai dengan kategori sangat baik, sebanyak 15 orang atau 37.5\% yang memperoleh nilai dengan kategori baik, dan sebanyak 18 orang peserta didik atau 45\% yang memperoleh nilai dengan kategori cukup. Kemudian, sebanyak 7 orang peserta didik atau 17.5\% yang memperoleh nilai dengan kategori kurang, serta 0\% yang memperoleh nilai dengan kategori sangat kurang. Ada 3 aspek yang dinilai dalam keterampilan menulis eksposisi analilitis, yaitu bagian tesid, argumen dan penegasan ulang yang belum memenuhi kriteria ketuntasan minimal atau KBM yang telah ditentukan oleh sekolah.. Berdasarkan pembelajaran pada siklusI, perlu dirancang rencana tindakan untuk pembelajaran siklus II.Penyusunan tindakan siklus II perlu dilakukan dengan matang untuk memaksimalkan pelaksanaan tindakan pada siklus II.Kegiatan penting yang harus dilakukan oleh guru, yaitu menjelaskan kembali materi pelajaran yang belum dipahami peserta didik tentang menulis teks eksposisi analitis, yang berkaitan dengan bagaimana menulikan tesis dan penegasan 
ulang pada paragraf penutup. Hasil keterampilan menulis teks eksposisi analitis pada sikllus II sudah mengalami peningkatan. Dari 40 orang peserta didik yang mengikuti tes praktik,5 orang peserta didik atau $12.5 \%$ memperoleh nilai antara 85-100 dengan kategori sangat baik, 27 orang peserta didik atau $67.5 \%$ memperoleh nilai antara 70-84 dengan kategori baik, 8 orang peserta didik atau 20\% memperoleh nilai antara 55-69 dengan kategori cukup. Berdasarkan pemerolehan skor keterampilan menulis peserta didik pada tabel di atas, dapat disimpulkan bahwa secara klasikal penerapanstrategi Think Talk Write (TTW) untuk meningkatkan kemampuan menulis teks eksposisi analitis peserta didik kelas XI P2 SMK Negeri 2 Singaraja sudah dikatakan berhasil.

Peningkatan skor rata-rata kelas terjadi pada pembelajaran siklus II.Peningkatan yang tampak, yaitu pada siklus I skor rata-rata sebesar 70 meningkat menjadi 76 pada siklus II.Peningkatan hasil belajar keterampilan menulis teks eksposisi analitis terjadi sebesar 6 point. Dengan peningkatan nilai rata-rata kelas pada siklus II tersebut, dapat dinyatakan bahwa pelaksanaan tindakan tindakan pada siklus II lebih baik daripada pelaksanaan tindakan pada siklus I.

\section{Simpulan Dan Saran}

Berdasarkan deskripsi hasil penelitian dan pembahasan yang telah diuraikan pada bab sebelumnya dapat disimpulkan bahwa penerapan strategi Think Talk Write (TTW) dapat meningkatkan kualitas pembelajaran menulis teks eksposisi analitispeserta didik. Keterampilan menulis teks teks eksposisi analitis dengan penerapan strategi Think Talk Write (TTW) meningkat.Peningkatan ini dapat dilihat dari hasil rata-rata nilai pada pratindakan, siklus I, dan siklus II.Pada pembelajaran pratindakan, hasil pembelajaran peserta didik mencapai rata-rata 62. Kemudian pada siklus I meningkat menjadi 70 .dan pada siklus II menjadi 76 dengan kategori baik. Hasil tersebut membuktikan bahwa strategi Think Talk Write (TTW) dalampemebelajaran menulis teks eksposisi analitis sangat efektif digunakan untuk mencapai keberhasilan proses pembelajaran dalam satu standar kompetensi.

Keterampilan menulis teks teks eksposisi analitis dengan penerapan strategi Think Talk Write (TTW) meningkat.Peningkatan ini dapat dilihat dari hasil rata-rata nilai pada pratindakan, siklus I, dan siklus II.Pada pembelajaran pratindakan, hasil pembelajaran peserta didik mencapai rata-rata 62 . Kemudian pada siklus I meningkat menjadi 70 .dan pada siklus II menjadi 76 dengan kategori baik. Hasil tersebut membuktikan bahwa strategi Think Talk Write (TTW) dalampemebelajaran menulis teks eksposisi analitis sangat efektif digunakan untuk mencapai keberhasilan proses pembelajaran dalam satu standar kompetensi.

Respons peserta didik dalam mencapai pembelajaran menulis teks eksposisi analitis dengan menggunakan strategi Think Talk Write (TTW) tergolong sangat baik.Pada siklus I, rata-rata respons siswa mencapai 44 dengan kategori baik.Pada siklus II meningkat dengan rata-rata 46 atau meningkat 2 poin dengan kategori sangat baik.

\section{Daftar Rujukan}

Agus Suriamiharja, dkk. 1996. Petunjuk Praktis Menulis. Jakarta: Departemen

Akhadiah, Sabarti. 1988. Pembinaan Kemampuan Menulis Bahasa Indonesia. Jakarta: Erlangga.

Arikunto, Suharsimi dkk. 2006. Penelitian Tindakan Kelas. Jakarta: Bumi Aksara.

Arikunto, Suharsimi. 2008. Manajemen Pendidikan. Yogyakarta: Aditya Media

Ariyanti Dwi Pratiwi, Ach. Fatchan, Purwanto . Penerapan Model Pembelajaran Thınk Talk Write (Ttw) Untuk Menıngkatkan Kemampuan Berkomunıkası Siswa Secara Tertulıs. Universitas Negeri Malang.

Djamarah, Syaiful Bahri. 2010. Strategi Belajar Mengajar. Jakarta: PT Rineka Cipta.

Djuraid, Husun. 2009. Panduan Menulis Berita. Malang: UMM Press.

Enre, Fahrudin. 1998. Dasar-dasar Keterampilan Menulis. Jakarta: Depdikbud. 
Harjayanti, Eni. 2007. Peningkatan Kemampuan Menulis Cerpen Melalui Media Film Bagi Peserta didikKelas X SMAN 1 Bantul. FBS UNY.

Hastuti, Sri. 1982. Tulis Menulis. Yogyakarta: Penerbit Lukman.

Isdriani, Pudji. 2009. Seribu Pena Bahasa Indonesia untuk Kelas SMA/MA Kelas X. Jakarta: Erlangga.

Lidya Yanuarta,Joko Waluyo, Suratno. 2014.“Penerapan Model Pembelajaran Kooperatıf Tıpe Thınk, Talk, Write (Ttw) Dengan Teknık Talkıng Stıck dalam Menıngkatkan Karakter Dan Hasıl Belajar IpaBıologi. Jurnal Pancaran, Vol. 3, No. 3, hal 69-78, Agustus 2014.

Lusia Ari Sumirat. 2014."Efektifitas Strategi Pembelajaran Kooperatif Tipe Think-Talk-Write (TTW) Terhadap Kemampuan Komunikasi dan Disposisi Matematis Siswa". Jurnal Pendidikan dan Keguruan Vol. 1 No. 2, 2014

Kosasih. 2014. Strategi Belajar dan Pembelajaran. Bandung: Penerbit Yrama Widya

Madya, Suwarsih. 2006 . Panduan Penelitian Tindakan. Yogyakarta: Lembaga Penelitian IKIP Yogyakarta.

Moleong, Lexy J. 2006. Metodologi Penelitian Kulitatif. Bandung: PT Remaja Rosdakarya.

Nurlaelah,. 2014. Keefektifan Film Dokumenter Sebagai Media Pembelajaran Menulis Argumentasi Pada Peserta didikKelas X SMA Tiga Maret Sleman Yogyakarta. FBS UNY.

Nurgiyantoro. 2001. Penelitian dan Pengajaran Bahasa dan Sastra. Yogyakarta: Universitas Gajah Mada

Nurgiyantoro, Burhan. 2009. Penilaian dalam Pengajaran Bahasa dan Sastra. Yogyakarta: BFFEYogyakarta. 2009. Teori Pengkajian Fiksi.

Rudi Hidayat, Choirul Huda, Qoriati Mushafanah (2017). Keefektifan Model Pembelajaran Think Talk Write Berbantu Media Puzzle Terhadap Hasil Belajar Siswa Kelas V Mata Pelajaran IPS SD Negeri Kutosari 02 Batang. Jurnal Ilmiah Sekolah Dasar. Vol.1 (3) pp. 179-185.

Sadiman, A, dkk. 2012. Media pendidikan (pengertian, pengembangan, dan pemanfaatan).Jakarta: Divisi Buku perguruan tinggi, PT Raja Grafindo Persada.

Sri Wahyuni. 2015. "Penerapan Strategi Think Talk Write (Ttw) Untuk Meningkatkan Hasil Belajar Pkn Siswa Kelas Iv Sdn Sidomulyo 03 Semboro Tahun Pelajaran 2013/2014. Jurnal Pancaran, Vol. 4, No. 3, Hal 99-108, Agustus 2015.

Tarigan, Henry Guntur. 1994. Metodologi Pengjaran Bahasa Indonesia. Bandung Pustaka Setia. 